\title{
„PACIORKI MOZAIKOWE W OTWARTYM PALENISKU?”. KONTYNUACJA BADAŃ ${ }^{1}$
}

\author{
MOSAIC BEADS IN AN OPEN FURNACE. \\ CONTINUED RESEARCH ${ }^{2}$
}

\begin{abstract}
The aim of the experiment was to confirm the hypothesis about the possibility of Scandinavian bead makers crafting complex mosaic glass beads. For this purpose, raw glass material and tools from archaeological sites were examined. Metal tools and glass mosaic canes were made, for the purpose of the experiment, based on archaeological finds. All the glass beads were made during the experiment on a specially constructed open hearth. As a result of the experiments, the possibility of making mosaic glass beads on an open hearth was confirmed. A theoretical and practical procedure for making complex glass beads has been proposed.
\end{abstract}

Keywords: Ribe, Åhus, Early Medieval, mosaic glass beads, experimental archaeology.

\section{WPROWADZENIE}

W badaniach nad szklanymi paciorkami mozaikowymi z terenów Skandynawii wyróżnić można dwa stanowiska badaczy. Z jednej strony wskazują oni na sprowadzanie gotowych paciorków z pracowni usytuowanych na terenach dzisiejszych Włoch, bądź też pracowni egipskich czy syryjskich (Bencard 1978, s. 126; Calmer

* Wydział Historyczny UAM, Instytut Archeologii, Umultowska 89D, 61-614 Poznań, m4rta. krzyzanowska@gmail.com.

** Fachbereich Geschichts- und Kulturwissenschaften FU Berlin, Institut für Prähistorische Archäologie, Fabeckstraße 23-25, 14195 Berlin, The Excellence Cluster 264 Topoi, Hittorfstraße 18, 14195 Berlin, m4teuszfrankiewicz@gmail.com.

${ }^{1}$ Część pierwsza poświęcona wykonywaniu paciorków szklanych w otwartym palenisku opublikowana została w „Slavia Antiqua” LVI (2015).

2 Part one dedicated to manufacturing glass beads in an open hearth was published in Slavia Antiqua LVI (2015) 
1977, s. 99). Z drugiej strony, na możliwość wykonywania niektórych typów paciorków na miejscu, przez wykwalifikowanych szklarzy, o czym miałyby świadczyć znajdowane półfabrykaty w postaci pałeczek mozaikowych (Bencard 1978, s. 126; Calmer 1977, s. 99). Brakuje natomiast (niemożliwość rozpoznania) produktów nieudanych owych paciorków, co nie pozwala na ustalenie sposobu ich produkcji.

Niniejszy artykuł opisuje kolejny etap eksperymentów związanych z próbą odtworzenia technik i sprawdzenia możliwości wykonywania paciorków szklanych w otwartym palenisku. Postawiona hipoteza zakłada, że istnieje możliwość wykonywania niektórych typów paciorków mozaikowych z gotowych półfabrykatów i przy użyciu prostych, łatwo dostępnych narzędzi w otwartym palenisku.

\section{BAZA ŹRÓDŁOWA}

Podstawą do przeprowadzania eksperymentu były znaleziska pochodzące z dwóch stanowisk: Ribe (Dania) i Åhus (Szwecja), gdzie zadukumentowano pracownie szklarskie z występującymi tam półfabrykatami w postacie pałek mozaikowych.

Stanowisko w Ribe badane było w latach 1970-1976. Datowane jest od okresu wpływów rzymskich aż do XI wieku. Pozyskano około 2800 fragmentów szkła; wśród nich $26 \%$ to całe paciorki lub ich fragmenty, 20\% pałeczki szklane, 21\% Tassera, 20\% odpady i 13\% kawałki szkieł naczyniowych (Bencard 1978, s. 124). Pośród 360 pałeczek szklanych około 18\% stanowiły pałeczki mozaikowe.

W dwóch horyzontach datowanych na VIII i IX w. odnaleziono paleniska, które charakteryzowały się gładką powierzchnią, brakiem wgłębień czy podwyższonych brzegów. Wymiary ich wahały się pomiędzy 50-60 cm długości i 25-30 cm szerokości. W jednym palenisku odnaleziono wypaloną glinianą dyszę do miechów (Bencard 1978, s. 124, Krzyżanowska i Frankiewicz 2015). W trakcie badań pozyskano również narzędzia, takie jak: metalowy przedmiot o spiczastym zakończeniu i drewnianej rękojeści, który można interpretować jako mandrelę, oraz metalowa patelnia z gładką powierzchnią i krótką rączką. Oba przedmioty sugerować mogą miejscową produkcję paciorków szklanych (Bencard 1978, s. 131).

Badania archeologiczne na stanowisku Åhus (południowa Szwecja) były prowadzone w latach 1979-1984. Stanowisko to datowane jest na początek pierwszej połowy VIII w. n.e. Na przebadanym terenie odkryto głównie pozostałości po jamach oraz paleniskach. Badacze uważają, że działalność w tym miejscu była sezonowa (Callmer i Henderson 1991, s. 143).

Łącznie znaleziono około 71896 przedmiotów szklanych, w tym 856 fragmentów szklanych naczyń, które nie były wykorzystywane przy produkcji paciorków. Produkcja paciorków szklanych opierała się na importowanych półfabrykatach. Wśród nich zarejestrowano 902 fragmenty wcześniej przygotowanych pałeczek 


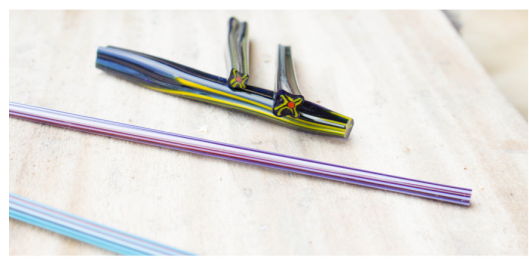

A

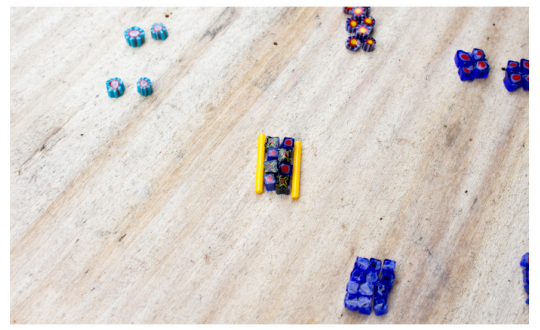

$\mathrm{C}$

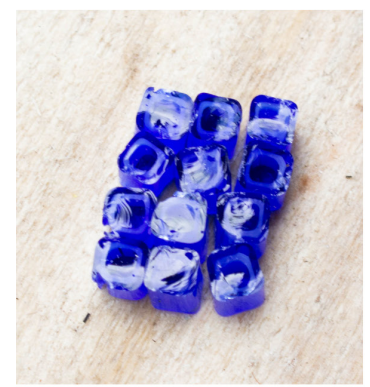

$\mathrm{E}$

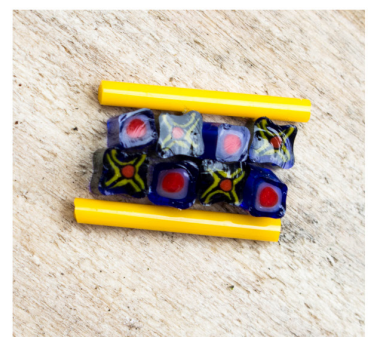

G

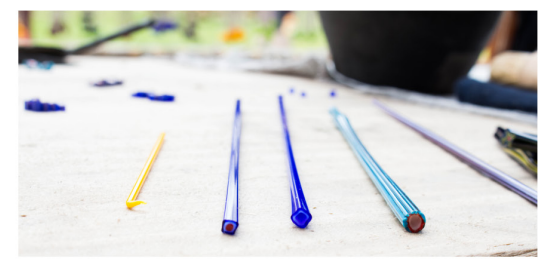

B

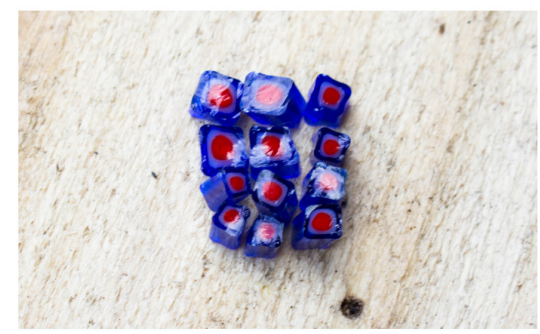

$\mathrm{D}$

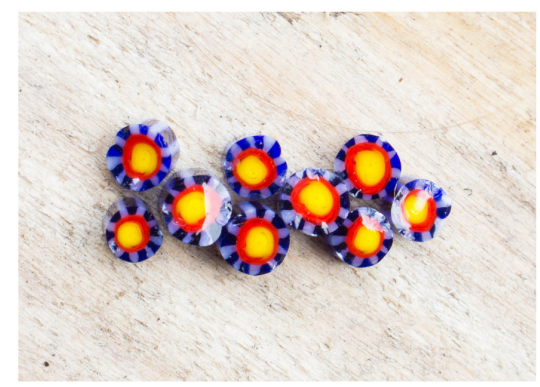

F

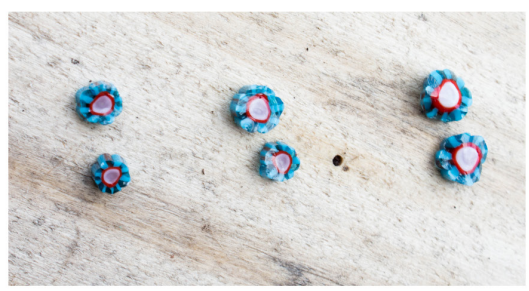

$\mathrm{H}$

Ryc. 1. Półfabrykaty i wstępnie ułożone paciorki mozaikowe

A-B - wykonane repliki mozaik przed pocięciem na mniejsze fragmenty; $\mathrm{C}-\mathrm{G}$ - ułożone paciorki mozaikowe przed przeniesieniem na metalową patelnię; $\mathrm{H}$ - mozaiki ułożone pod względem średnicy i wysokości (fot. M. Frankiewicz) 
mozaikowych. Autorzy opracowania sugerują, że szkło ogrzewane i trzymane było na metalowej patelni, a nie topione w tyglu (Callmer i Henderson 1991, s. 146).

Znajdowana w obrębie pracowni szklarskich duża liczba półfabrykatów, w tym również pałeczek mozaikowych, pozwala na wysunięcie hipotezy o możliwej miejscowej produkcji niektórych typów paciorków mozaikowych, a nie tylko ich imporcie na tereny Skandynawii. Z powodu braku pozostałości struktur pieców do produkcji paciorków szklanych podczas trwania eksperymentu korzystano, tak jak to miało miejsce wcześniej, z otwartego paleniska (Krzyżanowska i Frankiewicz 2015).

Prezentowana na zdjęciach i użyta w trakcie trwania eksperymentu mała żelazna patelnia (ryc 2. A) została wykonana na podstawie znaleziska znajdującego się w National Museum of Ireland - Archaeology w Dublinie. Widziana ona była przez autorów niniejszego artykułu i sfotografowana podczas ich wizyty w muzeum w styczniu 2015 roku. W literaturze przedmiotu obiekty takiego typu określane są jako narzędzia do emaliowania lub do podgrzewania fragmentów szkła przed wykonaniem paciorka szklanego (Bencard 1978, s. 131).

\section{JAK WYKONYWANO PACIORKI MOZAIKOWE?}

Produkcję paciorków mozaikowych rozpoczyna się poprzez wykonanie prętów mozaikowych. Na metalowy pręt nakłada się kolejno warstwy szkła, które odpowiednio się kształtuje, tak aby stworzyć finalny produkt. Następnie wyciąga się pręt o odpowiedniej średnicy i kształcie (okrągłym, kwadratowym lub prostokątnym). Gotowy pręt (w tym często również odprężony) jest cięty na mniejsze kawałki (Volkmann i Theune 2001, s. 526).

Aby wykonać paciorek mozaikowy, wzór należy ułożyć na podkładce i zgrzać ze sobą poszczególne elementy. Za pomocą odpowiednich form kształtuje się jego końcowy wygląd (Volkmann i Theune 2001, s. 526).

\section{EKSPERYMENT}

Eksperyment został przeprowadzony w dniach 29.04.-3.05.2017 r., podczas majowego festynu archeologicznego na terenie rekonstrukcji Wioski Wczesnopiastowskiej Muzeum Archeologicznego w Biskupinie.

Posługiwano się replikami narzędzi metalowych, które według autorów można korelować z produkcją paciorków szklanych, takimi jak: szczypce, mandrele, dłuto i mała żelazna patelnia o średnicy $75 \mathrm{~mm}$. W trakcie eksperymentu wykorzystywano miechy jednotaktowe, wykonane na podstawie przedstawień z Ramsund Carving (Szwecja) oraz fragmentu płaskorzeźby ze skrzydeł drzwi z Hylestad (Norwegia). 


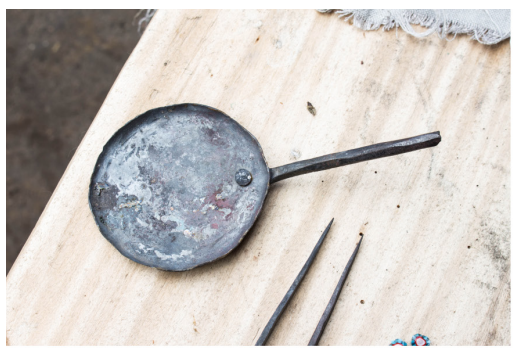

A

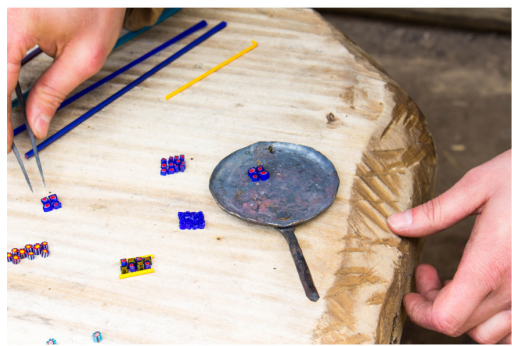

$\mathrm{C}$

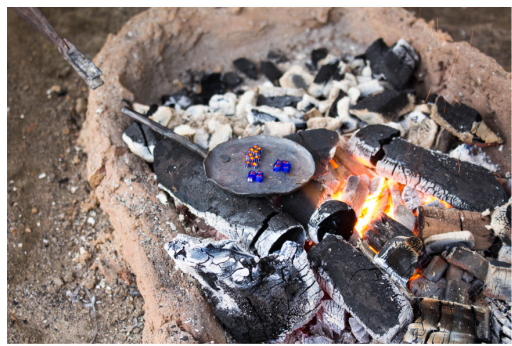

$\mathrm{E}$

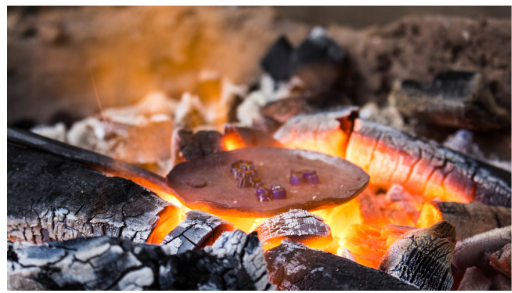

G

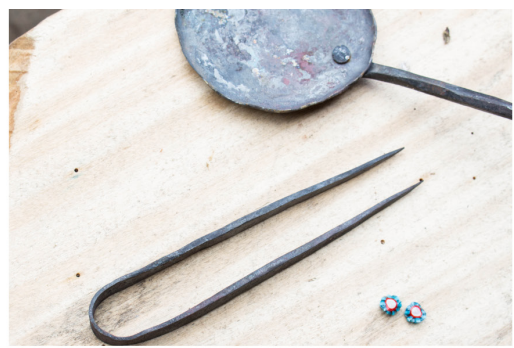

B

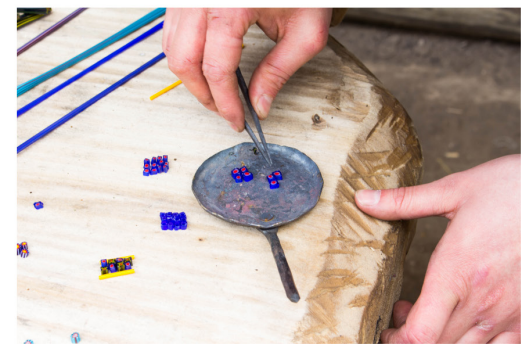

$\mathrm{D}$

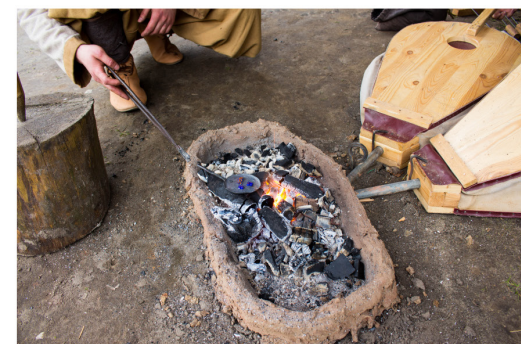

F

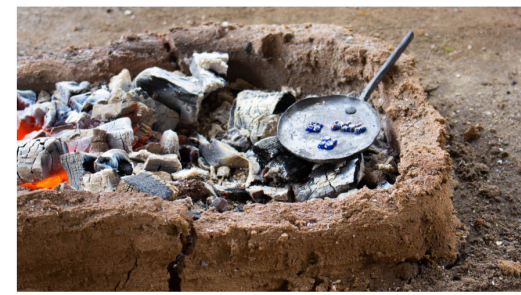

$\mathrm{H}$

Ryc. 2. Zgrzewanie mozaik

A - metalowa patelnia wykonana na podstawie inspiracji znaleziska z Dublina (Irlandia IX? w.); B - metalowa pęseta wykonana na podstawie znalezisk z terenów Polski i Skandynawii; C-D - przenoszenie wzoru na patelnie; E-G - zgrzewanie mozaiek; $\mathrm{H}$ - kontrolowane chłodzenie zgrzanych mozaiek (fot. A-B M. Frankiewicz; fot. C-H M. Krzyżanowska) 


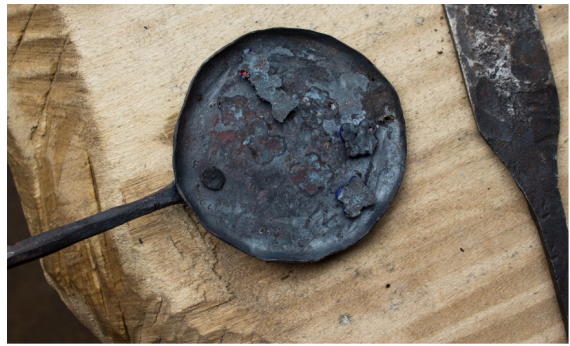

A

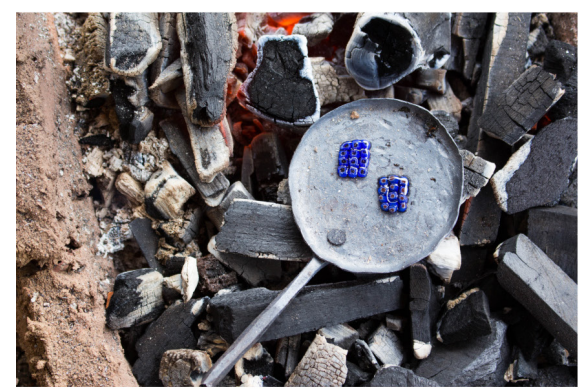

C

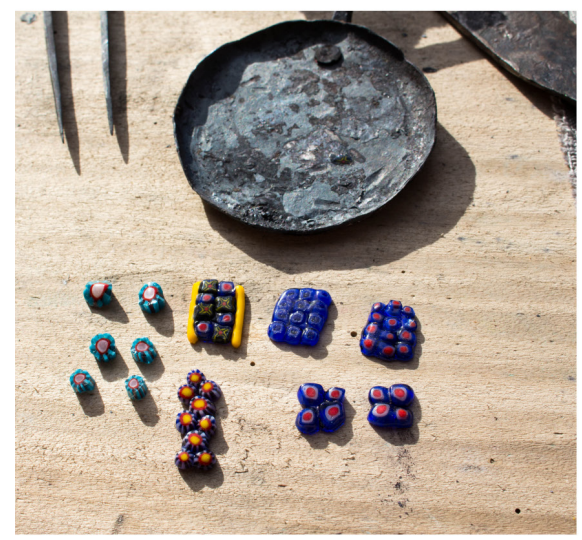

E

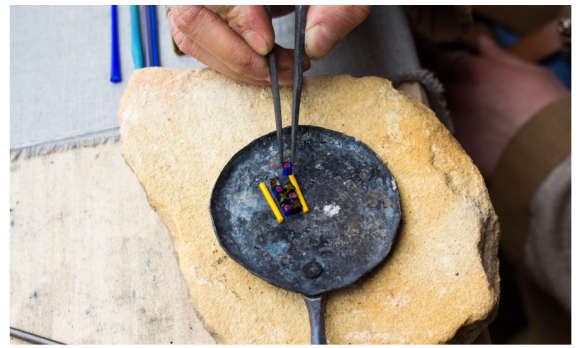

B

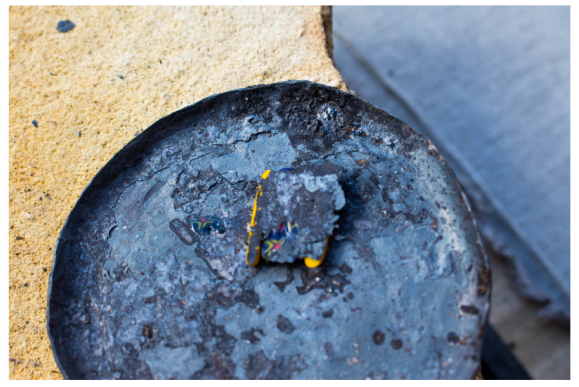

D

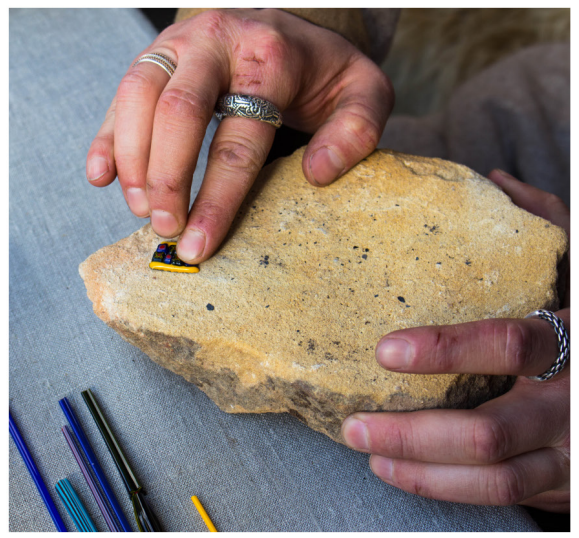

F

Ryc. 3. Kolejne etapy produkcyjne

A, D - odklejanie zgrzanych półfabrykatów od powierzchni patelni; B, C - układanie i zgrzewanie kolejnych paciorków; E - gotowe półfabrykaty; F - szlifowania powierzchni spodniej w celu usunięcia metalowego filmu (fot. M. Krzyżanowska) 


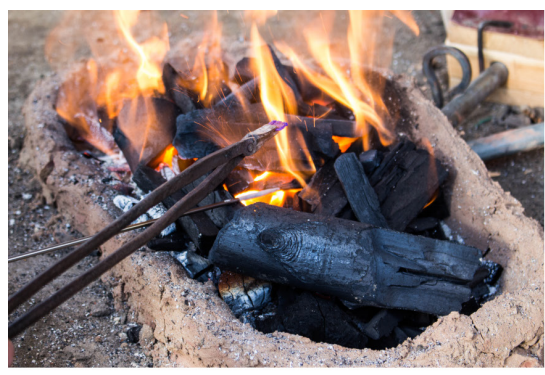

A

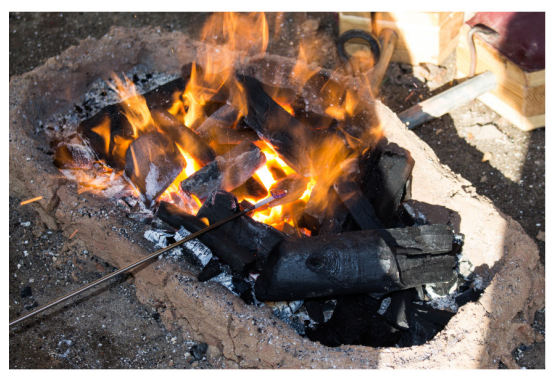

$\mathrm{C}$

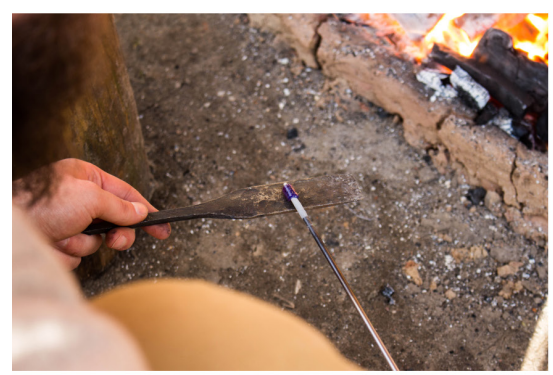

E

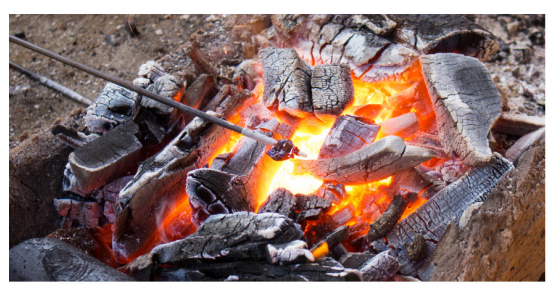

G

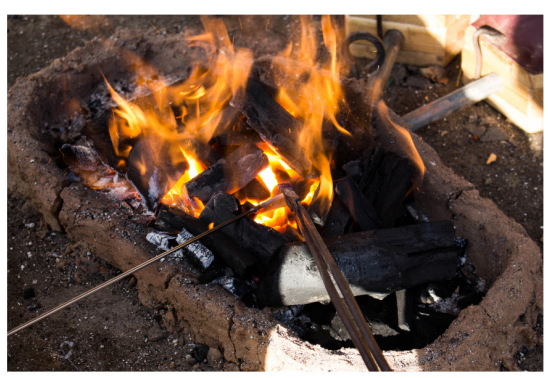

B

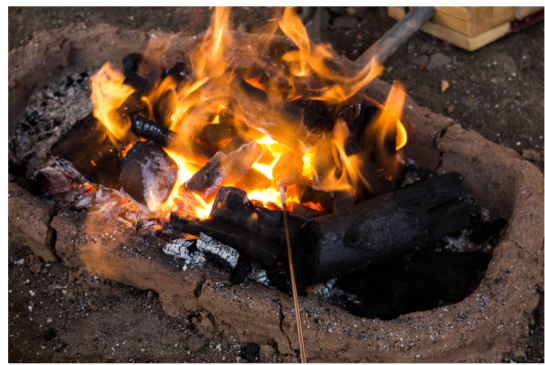

$\mathrm{D}$

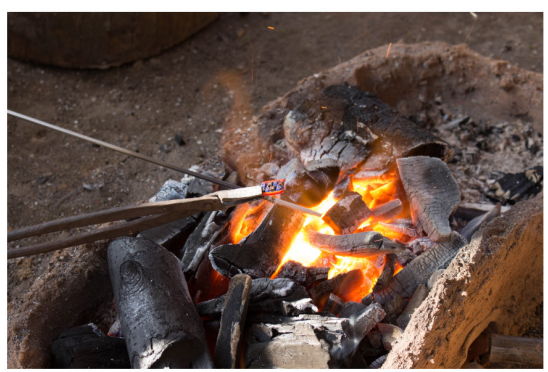

F

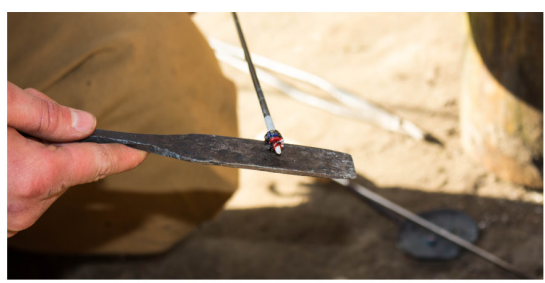

$\mathrm{H}$

Ryc. 4. Poszczególne etapy wykonywania paciorka mozaikowego

A, F - ogrzewanie; B - nakładanie; C, G - grawitacyjne formowanie; D - zgrzewanie; E, H - formowanie przy użyciu dłuta (fot. M. Krzyżanowska) 
$\mathrm{Na}$ potrzeby eksperymentu wykorzystano szkło sodowe pochodzące z huty Effetre Murano. Z niego wykonane zostały również przez autorów pręty mozaikowe na podstawie historycznych wzorów (ryc. 1. A, B). W trakcie eksperymentu prowadzona była dokumentacja zarówno filmowa, jak i fotograficzna.

Przed rozpoczęciem wykonywania paciorków zostało wylepione palenisko. Ze względu na miejsce przeprowadzania eksperymentu i brak możliwości wykonania otworu w ziemi zbudowano je na poziomie gruntu i wyniesiono ścianki na wysokość $+/-5 \mathrm{~cm}$ wraz z wyższą ścianką usytuowaną w punkcie umiejscowienia miechów (miało to zapobiec działaniu wysokiej temperatury na drewno miechów i ich ewentualnemu zapłonowi). Jest to inne rozwiązanie niż we wcześniej zaproponowanym palenisku (Krzyżanowska i Frankiewicz 2015).

Za pomocą nożyc do szkła pręty mozaikowe zostały pocięte na małe fragmenty o wysokości $+/-4 \mathrm{~mm}$ i wstępnie ułożone (ryc. 1. C-H). Przy użyciu metalowej pęsety (ryc. 2. B) przeniesiono wzory na metalową patelnię (ryc. 2. C, D; ryc. 3. B). Kolejnym krokiem było stopniowe ogrzewanie szkła w palenisku (ryc. 2. E, F) i zgrzanie ze sobą elementów mozaik (ryc. 2. G). Następnie patelnię ustawiono z boku paleniska, aby stopniowo wystudzić gotowy półfabrykat (ryc. 2. H; ryc. 3. C).

Po wystudzeniu zgrzane mozaiki podważano dłutem i odklejano od powierzchni patelni. Na rycinie 3. A i D można zauważyć, że na spodniej części pozostała cienka warstwa utlenionego żelaza. Gotowe półfabrykaty (ryc. 3. E) należało następnie przeszlifować w celu usunięcia warstwy metalu (ryc. 3. F).

Etap wykonania paciorków mozaikowych został rozpoczęty poprzez nałożenie separatora na mandrele. Następnie uformowane płytki zostały umieszczone w metalowych szczypcach i stopniowo ogrzewane, aby uniknąć szoku termicznego (ryc. 4. A). Sukcesywnie zwiększano temperaturę w palenisku oraz obniżano płytkę szklaną. Gdy zaobserwowano rozpoczęcie się procesu topienia szkła, płytkę mozaikową położono na mandreli (ryc. 4. B) i grawitacyjnie zaczęto formować paciorek (ryc. 4. C), ostateczną jego formę wykonano za pomocą metalowego dłuta (ryc. 4. E). Wszystkie wyżej opisane czynności zostały powtórzone przy produkcji każdego paciorka mozaikowego (ryc. 4. F-H).

$\mathrm{W}$ trakcie eksperymentu powstały również paciorki składające się z dwóch fragmentów mozaiki, a także paciorki z mozaikami wklejonymi w bazę. Fragmenty umieszczono na metalowej patelni i stopniowo je ogrzano, następnie rozgrzano mandrelę, a metalową patelnię z mozaikami umieszczono bliżej środka paleniska, gdzie panowała wysoka temperatura (ryc. 5. A). Gdy mandrela była wystarczająco rozgrzana i zauważono nadtapianie się górnej powierzchni mozaiki, aplikowano półfabrykat poprzez wciśnięcie w niego mandreli (ryc. 5. B). Oba fragmenty zgrzano, a końcowe formowanie odbywało się za pomocą metalowego dłuta (ryc. 5. C-D).

Jak wspomniano wcześniej, wykonano również paciorki z wtopionymi w bazę fragmentami mozaiki (ryc. 7. E, F). Na metalowej patelni umieszczono przygotowane wcześniej i pocięte mozaiki, które następnie stopniowo ogrzano. Na mandre- 


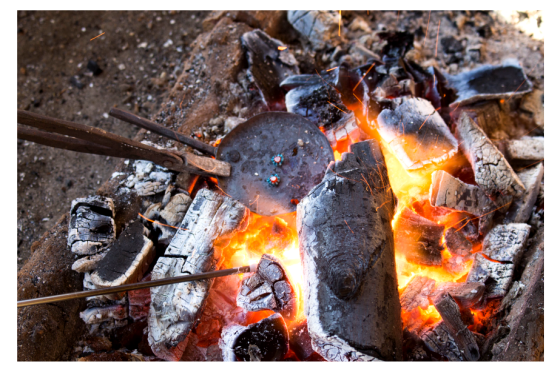

A

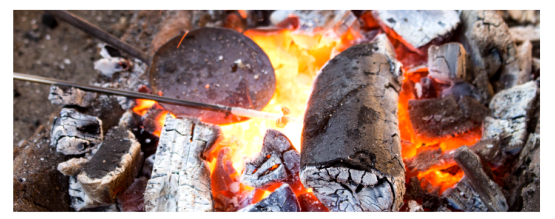

$\mathrm{C}$

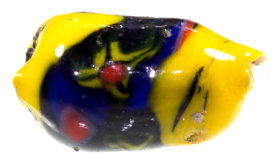

$\mathrm{E}$

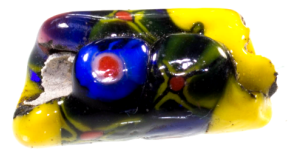

G

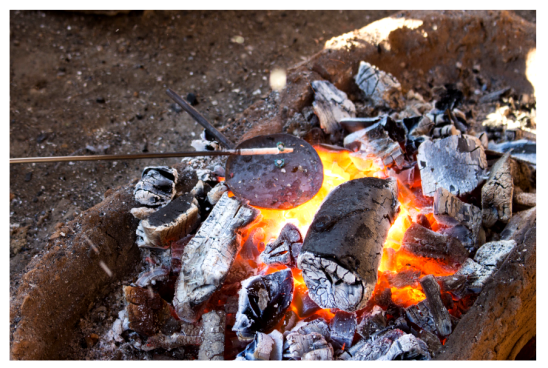

B

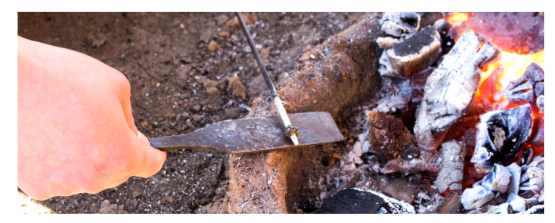

$\mathrm{D}$

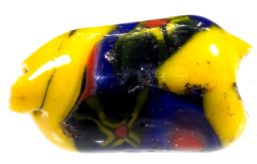

F

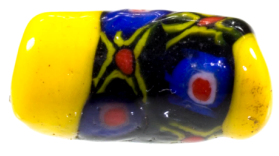

$\mathrm{H}$

Ryc. 5. Wykonywanie paciorka mozaikowego złożonego z dwóch fragmentów oraz gotowe wyroby

A - ogrzewanie na metalowej patelni muriini, nagrzewanie mandreli; B - nakładanie muriini na mandrele; C - zgrzewanie; D - formowanie; E-H - gotowe wyroby (fot. A-D M. Krzyżanowska; fot. E-H M. Frankiewicz) 


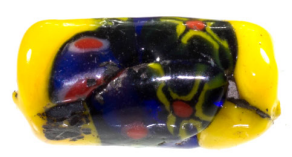

A

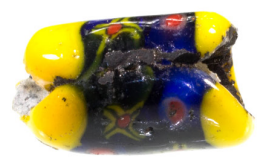

C

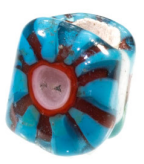

E

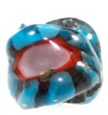

G

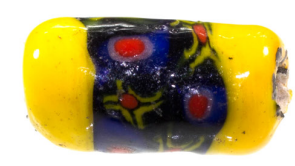

B

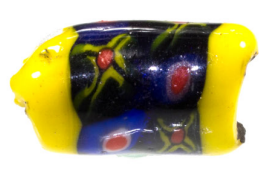

D

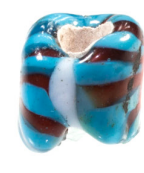

F

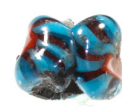

$\mathrm{H}$

Ryc. 6. Gotowe wyroby. A-D paciorki wykonane z kilku elementów; E-H paciorki wykonane z dwóch elementów. (fot. M. Frankiewicz) 

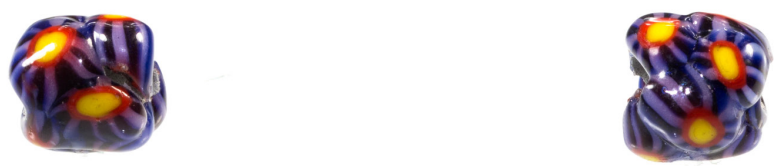

A

B
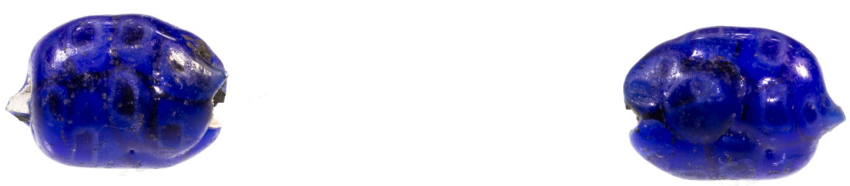

$\mathrm{C}$

$\mathrm{D}$
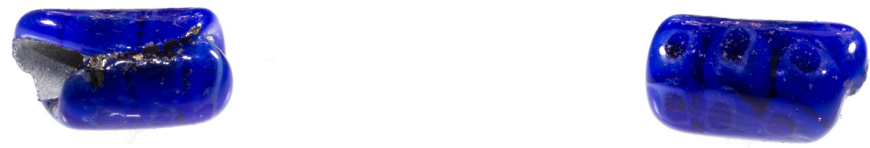

$\mathrm{E}$

$\mathrm{F}$
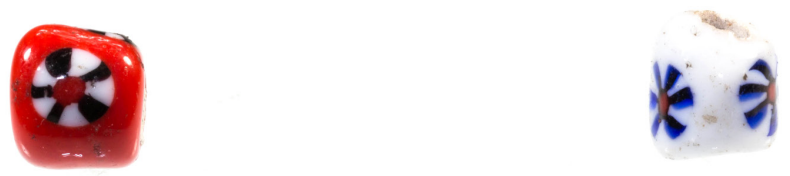

G

$\mathrm{H}$

Ryc. 7. Gotowe wyroby

A-F - paciorki wykonane z kilku elementów; G-H - paciorki wykonane poprzez nałożenie na bazę millefiori i wtopienie ich (fot. M. Frankiewicz) 
lę nałożono jednokolorową bazę (paciorek płaskokulisty). Gdy szkło bazy było miękkie i lekko płynne, mozaikę wciśnięto w paciorek i wtopiono poprzez formowanie grawitacyjne. Ostateczną formę paciorka uzyskano za pomocą metalowego dłuta.

Wszystkie paciorki w trakcie eksperymentu były stopniowo wychłodzone w specjalnym piasku. Na potrzeby tego eksperymentu zrezygnowano z historycznych metod odprężania paciorków szklanych.

\section{WYNIKI}

Zaproponowany w artykule sposób wykonywania paciorków mozaikowych pozwolił na wytworzenie zarówno prostych, jak i bardziej skomplikowanych wzorów. Przyjęte założenia i metodyka potwierdziły możliwość wykonywania paciorków mozaikowych $\mathrm{w}$ otwartym palenisku za pomocą istniejących $\mathrm{w}$ tamtym czasie narzędzi. Zgrzewanie płytek było czynnością pracochłonną i wymagało dużego doświadczenia w odczytywaniu temperatury szkła na metalowej płytce. Zbyt mocne zgrzanie (upłynnianie) szkła powoduje bowiem przywarcie płytki do powierzchni metalu, co prowadzić może do uszkodzenia półfabrykatu. Użycie dobrze nawęglonej żelaznej patelni pozwoliło na zdjęcie z niej zgrzanych mozaik. Pozostała na spodzie szklanej płytki cienka warstwa żelaza została usunięta bez uszkadzania płytki.

Przy aplikacji płytek na mandrelę również należało cały czas kontrolować proces, szkło musiało być plastyczne i na tyle twarde, by wykonany wcześniej wzór „utrzymał się” w trakcie formowania paciorka. Podczas ostatecznego formowania paciorka żelazne dłuto nie było podgrzewane, dzięki temu odbierało nadmiar temperatury ze szkła, pozwalając na precyzyjne formowanie i uniknięcie przyklejenia się szkła do narzędzia.

Eksperyment wykazał, że wystarczyło dwóch doświadczonych rzemieślników do przeprowadzenia całości procesu.

\section{Opis wykonanych paciorków:}

Paciorek 1 - ryc. 5. E, F

Na skutek zbyt mocnego upłynnienia szkło koloru żółtego znajdujące się na boku paciorka „rozlało się” za bardzo w środek paciorka, zniekształcając wzór; wymiary paciorka: długość $15 \mathrm{~mm}$, wysokość $9 \mathrm{~mm}$.

Paciorek 2 - ryc. 5. G, H

Zbyt szybkie umieszczenie szkła w wysokiej temperaturze spowodowało pęknięcie żółtego szkła z boku paciorka i jego „odskoczenie” od wzoru; wymiary paciorka: długość $17 \mathrm{~mm}$, wysokość $9 \mathrm{~mm}$. 
Paciorek 3 - ryc. 6 . A, B

Widoczna jest linia odcinająca dwa końce płytki, na łączeniu widoczny jest metalowy film; wymiary paciorka: długość $17 \mathrm{~mm}$, wysokość $8 \mathrm{~mm}$.

Paciorek 4 - ryc. 6. C, D

Widoczna jest linia łączenia paciorka, jak także film metalowy na krawędzi, żółty element był przygotowany zbyt krótki, przez co nie ma ciągłości wzoru boku; wymiary paciorka: długość $14 \mathrm{~mm}$, wysokość $7 \mathrm{~mm}$.

Paciorek 5 - ryc. 6. E, F

Paciorek wykonany z dwóch elementów, na jednym z boków i miejscu zgrzania widać zanieczyszczenie w postaci przyklejonego fragmentu białego szkła; wymiary: długość $8 \mathrm{~mm}$, wysokość $8 \mathrm{~mm}$.

Paciorek 6 - ryc. 6. G, H

Paciorek wykonany z dwóch elementów, widoczna jest linia łączenia; wymiary: długość $6 \mathrm{~mm}$, wysokość $7 \mathrm{~mm}$.

Paciorek 7 - ryc. 7. A, B

Paciorek mozaikowy wykonany ze zgrzanych elementów, brak kulistości paciorka spowodowany jest przerwaniem procesu z obawy o zapadnięcie się środka mozaik i zlania wzoru; wymiary: długość $10 \mathrm{~mm}$, wysokość $9 \mathrm{~mm}$.

Paciorek 8 - ryc. 7. C, D

Paciorek wykonany ze zgrzanych elementów, brak widocznej linii łączenia (końca) wcześniej przygotowanej płytki; wymiary: długość $12 \mathrm{~mm}$, wysokość $10 \mathrm{~mm}$ w najszerszym miejscu.

Paciorek 9 - ryc. 7. E, F

Paciorek wykonany ze zgrzanych elementów, widoczna linia łączenia końców płytki, nierówność paciorka na jednym z boków spowodowana jest odłamaniem się jednej mozaiki w trakcie nakładania ich na mandrele; wymiary: długość $14 \mathrm{~mm}$, wysokość $8 \mathrm{~mm}$.

Paciorek 10 - ryc. $7 . \mathrm{G}$

Paciorek z wtopionym millefiori, baza wykonana z czerwonego szkła, mozaika ma czerwone centrum, czarne promienie i białe wypełnienia; wymiary: długość $8 \mathrm{~mm}$, wysokość $8 \mathrm{~mm}$.

Paciorek 11 - ryc. 7. H

Paciorek z wtopionym millefiori, baza wykonana z białego szkła, mozaika ma czerwone centrum z czarnym obwodem, kobaltowe promienie i białe wypełnienie; wymiary: długość $8 \mathrm{~mm}$, wysokość $8 \mathrm{~mm}$. 


\section{LITERATURA}

Bencard M. 1978, Wikingerzeitliches Handwerk in Ribe. Eine übersicht, „Acta Archaeologica”, z. 49, s. $113-138$.

Callmer J. 1977, Trade Beads And Bead Trade In Scandinavia ca. 800-1000 A.D., Lund.

Callmer J., Henderson J. 1991, Glassworking at Ahus, South Sweden [Skane, 8th century AD] „Labortaiv Arkeologi”, z. 5, s. 143-154.

Krzyżanowska M., Frankiewicz M. 2015, An Archaeological experiment with Early Medieval glass bead production in an open hearth - results, „Slavia Antiqua”, t. 56, s.105-125.

Volkman A., Theune C. 2001, Merowingerzeitliche Millefioriperlen in Mitteleuropa. „Ethnographisch-archäologische Zeitschrift" z. 42, s. 521-553. 